\title{
Statyba
}

\section{ANALYSIS OF CONTACT PROBLEMS IN ELASTIC-PLASTIC METAL SEALS}

\section{Eidukynas \& R. Barauskas}

To cite this article: V. Eidukynas \& R. Barauskas (1997) ANALYSIS OF CONTACT PROBLEMS IN ELASTIC_PLASTIC METAL SEALS, Statyba, 3:10, 37-42, DOI: 10.1080/13921525.1997.10531682

To link to this article: https://doi.org/10.1080/13921525.1997.10531682

曲 Published online: 26 Jul 2012.

6 Submit your article to this journal $\pi$

III Article views: 81 


\title{
TAMPRIŲJŲ METALINIŲ SANDARIKLIŲ KONTAKTINĖS SĄVEIKOS TYRMMAS
}

\author{
V. Eidukynas, R. Barauskas
}

\section{Iৃvadas}

Kompiuteriniy projektavimo metody plètojimas leidžia kritiškai vertinti nusistovèjusias kai kurių techniniu objekty projektavimo metodikas. Projektuojant įmanoma atlikti sudètingesnius skaixiavimus, nei buvo iprasta inžinerinėje veikloje. Realu, kad siaip jau gana sudètingi tamprumo ir plastiškumo teorijos kontaktiniai uždaviniai artimiausiu laiku gali tapti sandarinimo irenginiy projektavimo pagrindu.

Apžvelgus sandarinimo įrenginių projektavimo metodikas galima pasakyti, kad daugeliu atveju skaiciavimams taikomos labai supaprastintos empirinès formulès. Kontakte vykstantys procesai dažniausiai visai nevertinami, nes analitǐ̌kai tai padaryti labai sunku. Skaitiniai metodai ir sparčiai besivystanti kompiuterinè technika leidžia spręsti tokius uždavinius be didesnių supaprastinimų. Sprendžiant kontaktinius uždavinius pasinaudota žymių mokslininku G. Herco, V. Aleksandrovo, K Džonsono, J. Lubliner ir kt. darbuose sukaupta patirtimi $[1,2,3]$.

\section{Tyrimy tikslas ir metodas}

Šio darbo tikslas - ištirti tipinių metalinių eksploatacinių apkrovų veikiamų sandariklių deformuotujų būvių parametrus, paruošiant rekomendacijas praktinèms projektavimo reikmèms.

Sandarinimo elementų kontaktinès sąveikos uždaviniai dažniausiai būna fiziškai ir geometriškai netiesiniai, todèl labai svarbu teisingai aprašyti sandariklio medžiagos tampriąsias plastines savybes, ivertinant galimas dideles deformacijas ir aukštas temperatūras. Labai svarbu ir teisingai aprašyti kontaktinio uždavinio parametrus.

Todèl nors skaičiavimams ir naudota pažangi baigtinių elementų sistema ANSYS 5.0A [4], tik po jos testavimo buvo parinkti medžiagos tampriai plastinių savybių bei kontakto aprašymo parametrai, apskaiciuojant labiausiai paplitusius, veikiamus eksploataciniu apkrovy, tipinius tampriuosius metalinius sandariklius (kūginius, $V$ ir $\lambda$ tipo) ir ju dangų deformuotụjų būvių parametrus.

\section{Kūginiai sandarikliai}

Kūginis sandariklis naudojamas vamzdynų flansiniuose sujungimuose [5]. Sandarinimo principas čia grindžiamas nemažomis į sandarinamus paviršius remiančiųsi sandariklio briaunų plastinèmis deformacijomis ir sandariklio konstrukcijos tampriosiomis savybèmis, kompensuojančiomis sandarinamy pavirši geometrijos netobulumus ir sujungimą veikiančiu jègų sukeltus poslinkius. Küginio sandariklio skaičiavimo schema parodyta 1 pav.

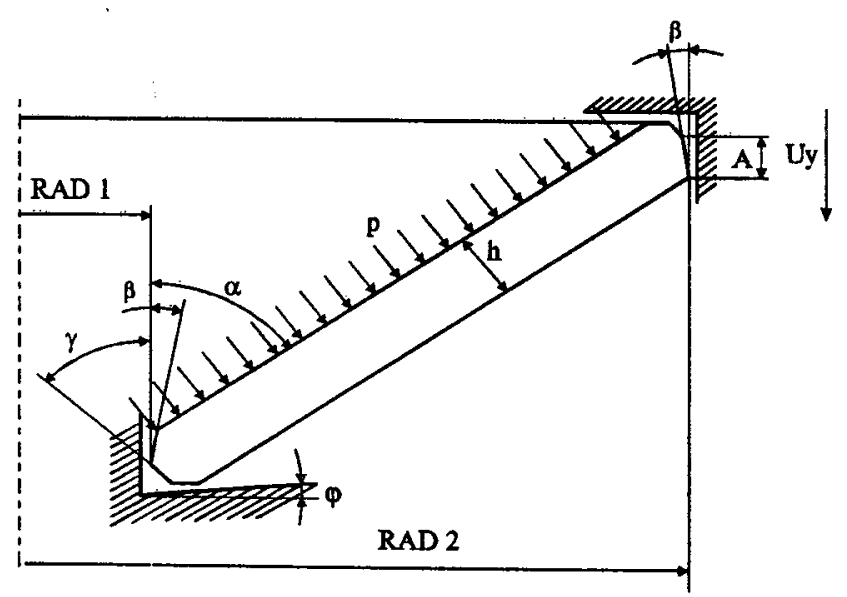

1 pav. Kūginio sandariklio skaičiavimo schema

Fig 1. Computational scheme of conical seal 
Sudarytos kontaktinès jègos priklausomybès nuo įveržimo $\delta$ (sandarinimo paviršiu suartẻjimo), esant skirtingoms medžiagos (nerūdijančio plieno) stiprejimo charakteristikoms, rodo, kad kontaktiné jèga nèra tiesiog proporcinga ịveržimo dydžiui. 2 pav. pateikiamos kūginio sandariklio (sąlyginis skersmuo $300 \mathrm{~mm}$ ) kontaktinès jègos priklausomybès nuo įveržimo $1-\mathrm{E}=2,1 \cdot 10^{5} \mathrm{MPa}, \sigma_{\mathrm{y}}=280 \mathrm{MPa}$, $\mathrm{E}_{\mathrm{k} 1}=7000 \mathrm{MPa}(\varepsilon \leq 0,0125), \mathrm{E}_{\mathrm{k} 2}=2500 \mathrm{MPa}$ $(0,0125<\varepsilon \leq 0,0125), \mathrm{E}_{\mathrm{k} 3}=600 \mathrm{MPa}(0,1<\varepsilon \leq 0,3)$, $E_{\mathrm{k} 4}=1000 \mathrm{MPa}(\varepsilon>0,3), 2-\mathrm{E}=2,1 \cdot 10^{5} \mathrm{MPa}$, $\sigma_{y}=200 \mathrm{MPa}, \mathrm{E}_{\mathrm{k}}=5 \cdot 10^{3} \mathrm{MPa} ; 3-\mathrm{E}=2,1 \cdot 10^{5} \mathrm{MPa}$, $\sigma_{\mathrm{y}}=500 \mathrm{MPa}, \mathrm{E}_{\mathrm{k}}=3 \cdot 10^{3} \mathrm{MPa}$.

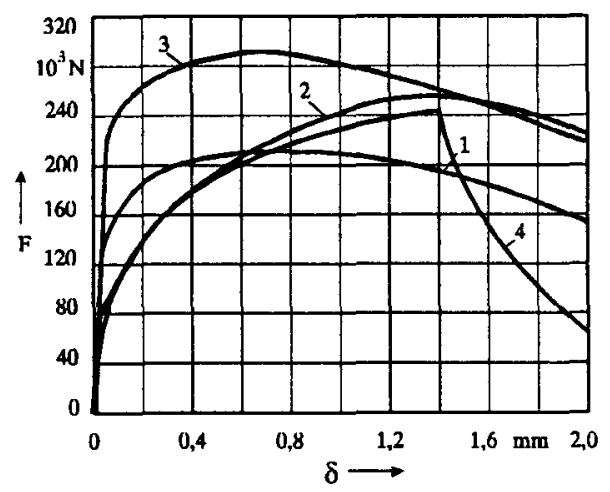

2 pav. Kūginio sandariklio kontaktinès jëgos priklausomybès nuo jiveržimo

Fig 2. The relation between contact force and deformation in conical seal

Nustatytas svarbiausias standartizuoty didesniu nei $100 \mathrm{~mm}$ skersmens kūginių sandarikliu deformavimo dèsningumas: kai apspaudimo dydis pagal medžiagos takumo ribą ir stipréjimo dèsnị viršija $0,7-1,3 \mathrm{~mm}$, sandariklis suklumpa, paprastai antraja nestabilumo forma. Praktiškai tai reiškia, kad sandariklis arba visiskai sugniuždomas, arba gerokai sumažja kontaktinè jèga, ir sujungimas gali isssihermetinti.

Tokio kūginio sandariklio $(\mathrm{RAD} 1=0,153 \mathrm{~m}$, $\mathrm{RAD2}=0,159 \mathrm{~m}, \mathrm{~h}=0,001 \mathrm{~m}, \mathrm{~A}=0,0007 \mathrm{~m}$, $\alpha=60^{\circ}, \beta=0^{\circ}, \varphi=10^{\circ}, \gamma=45^{\circ}, \mathrm{E}=2,1 \cdot 10^{5} \mathrm{MPa}$, $\sigma_{\mathrm{y}}=280 \mathrm{MPa}, \mathrm{E}_{\mathrm{k} 1}=7000 \mathrm{MPa}(\varepsilon \leq 0,0125)$, $\mathrm{E}_{\mathrm{k} 2}=2500 \mathrm{MPa}(0,0125<\varepsilon \leq 0,0125), \mathrm{E}_{\mathrm{k} 3}=1600 \mathrm{MPa}$ $\left.(0,1<\varepsilon \leq 0,3), \mathrm{E}_{\mathrm{k} 4}=1000 \mathrm{MPa}(\varepsilon>0,3), v=0,3\right)$ deformuota forma ir plastiniu deformaciju izolinijos vieno iš apkrovimo žingsnių metu (sandariklis ivveržtas 1,2 mm) parodyti 3 pav.

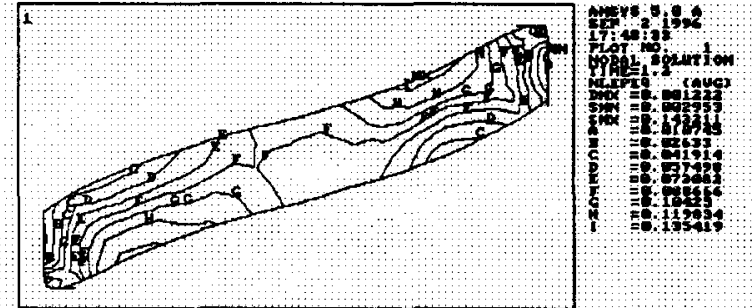

3 pav. Kūginio sandariklio plastiniu deformacijų izolinijos, kai jis juveržtas $1,2 \mathrm{~mm}$

Fig 3. Contours of equivalent plastic strains of conical seal

Galima daryti išvadą, kad standartizuotose, nors ir nepakankamai ištirtose sio tipo sandariklių konstrukcijose kraštinès sąlygos pasireikšti pirmajai nestabilumo formai yra nepalankios. Tokie skaičiavimu rezultatai, kai pasireiškia tik antroji nestabilumo forma, padèjo suprasti eksperimentu rezultatus, nes ir jų metu deformuotojo sandariklio skerspjūvis buvo $\mathrm{S}$ formos. Panašiai sandariklis deformuojasi ir veikiamas skirtingџ temperatūru darbo slègių. Tačiau kai slègiai dideli (didesni nei 10 $\mathrm{MPa}$ ), $\mathrm{S}$ forma tampa netaisyklinga ir yra geometriškai panašesnè i i pirmają nestabilumo formą. 2 pav. (kreivè 4) pateikiama îveržimo jègos priklausomybė nuo deformavimo dydžio, kai darbo terpès slègis $40 \mathrm{MPa}$. Matome, kad kontaktinè jèga padidèja ne daugiau kaip $10 \%$, nors stabilumas prarandamas kiek vèliau $(1,4 \mathrm{~mm})$.

Tai patvirtina ir mažesnių skersmenų sandarikliu skaičiavimai. Pavyzdžiui, esant sąlyginiam $70 \mathrm{~mm}$ skersmeniui, kritinès îveržimo jègos sumažèja maždaug du kartus, o stabilumą toks sandariklis praranda apspaudžiamas $0,7 \mathrm{~mm}$ sandarinamo paviršiaus eiga.

Realių kūginių sandariklių matmenų sklaida gali būti nemaža. Pavyzdžiui, kai sandarinimo įrenginio lizdo ir sandariklio matmenys yra $\varnothing 306 \mathrm{H} 8 / \mathrm{e} 9$ ir $\varnothing 318 \mathrm{H8} / \mathrm{f9}$, kampas $\alpha$ svyruoja nuo $61,50 \mathrm{iki} 65,7^{\circ}$, o bendras sandariklio aukštis $\mathrm{H}$ atitinkamai yra 2,784 . $3,288 \mathrm{~mm}$ (prieš sandarikli apspaudžiant). Taigi sandariklio posvyrio kampas kinta iki $4,2^{\circ}$, o aukstis iki $0,5 \mathrm{~mm}$. Akivaizdu, kad dèl tokios matmenu sklaidos kūginis sandariklis greitai praras stabilumą ir daugeliu atveju veiks nestabiliai. Be to, kūginiai sandarikliai greičiau gali prarasti stabilumą ir dèl formos nuokrypių. Tą puikiai iliustruoja sandariklių su nežymiai nusklembtomis briaunomis skaičiavimai. 


\section{4. $V$ ir $\lambda$ tip 4 sandarikliai}

$\mathrm{V}$ ir $\lambda$ tipų sandarikliai dèl didelio elastingumo gali kompensuoti statinius ir net $0,1-0,4 \mathrm{~mm}$ dinaminius poslinkius ir geometrinès formos nuokrypius [5]. Juos naudojant stabilumo problemos nekyla. Šio tipo sandarikliai paprastai gaminami su minkštomis metalinèmis ar polimerinèmis dangomis. Sandarinimo ketera deformuojasi labai sudètingai, nes kontaktuojantis pavirsius, padengtas danga, slysta ir rieda sandarinamu paviršiumi. Šiame darbe toks uždavinys sprendžiamas kompleksiškai, dangai skaiciuoti taikant submodeliavimo principa.

Kadangi linginis sandariklis pagal savo funkcinę paskirtị turi ne mažiau kaip du dažniausiai identiškus tamprius elementus, skaičiuoti galima tik vieną iš jų. Tai sumažina uždavinio apimti. Tipinio tampraus elemento $V$ ar $\lambda$ tipo sandariklio geometrija ir ją nusakantys parametrai pateikti 4 pav. Modelis sudarytas taip, kad lengvai būtų galima keisti sandariklio geometriją ir apkrovas. Pateikiami vieno tokio sandariklio $(\mathrm{RADX}=3 \mathrm{~mm}, \mathrm{~S} 1=5 \mathrm{~mm}$, $\mathrm{H} 1=1,7 \mathrm{~mm}, \mathrm{H} 2=0,5 \mathrm{~mm}, \mathrm{~S} 2=0,5 \mathrm{~mm}, \mathrm{H} 3=2,8 \mathrm{~mm}$, $\mathrm{S} 3=5,5 \mathrm{~mm}, \mathrm{RAD} 1=\mathrm{RAD} 2=\mathrm{RAD3}=1 \mathrm{~mm}$, RADY $=4 \mathrm{~mm}, \mathrm{RADC}=30 \mathrm{~mm}, \mathrm{DD}=0,1 \mathrm{~mm}$, $\delta=0,12 \mathrm{~mm}, \mathrm{E}=2,1 \cdot 10^{5} \mathrm{MPa}, v=0,3$ ) skaiciavimo rezultatai.

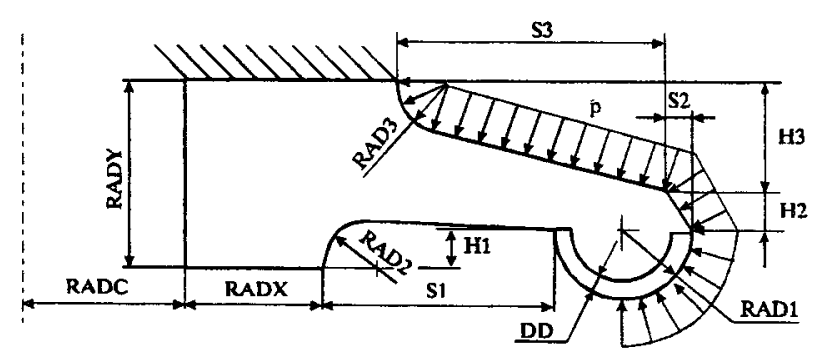

4 pav. $V$ ir $\lambda$ tipo sandarikliy skaiciavimo schema

Fig 4. Computational scheme of $V$ and $\lambda$ form seal

Sprendžiant iš įtempimų pasiskirstymo (5 pav.), tampraus elemento forma ir matmenys yra parinkti racionaliai, nes nèra ryškios įtempimų koncentracijos skerspjūvio perèjimo zonose. Siekiant ji dar pagerinti, lingès kūgiškumą, kuris šiuo atveju sudaro $16^{\circ}$, derètų šiek tiek padidinti, tada būtų galima priartèti prie beveik tolygaus įtempimų pasiskirstymo paviršiniuose kevalo sluoksniuose (6 pav.).

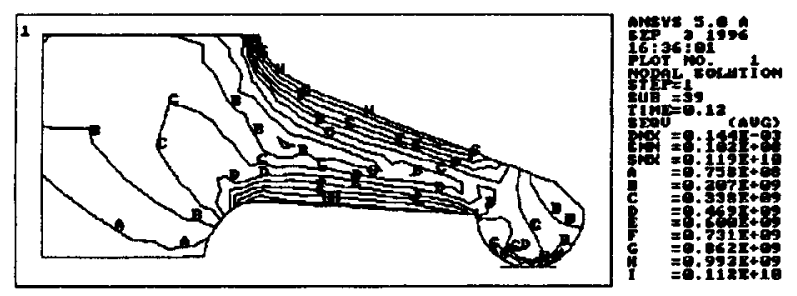

5 pav. Linginio sandariklio ịtempimų intensyvumo izolinijos, kai jis îveržtas $0,12 \mathrm{~mm}$

Fig 5. Contours of stresses intensity of cantilever spring seal

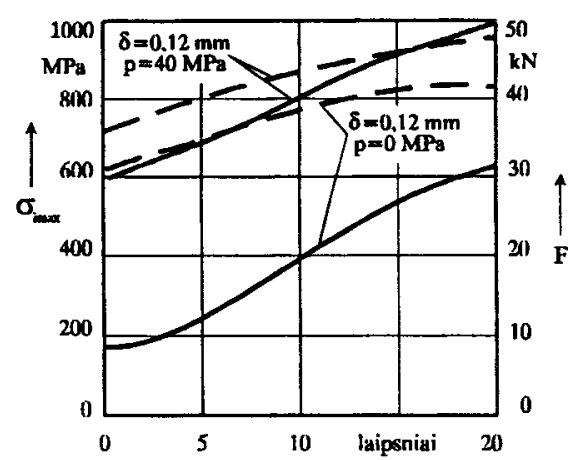

6 pav. Linginio sandariklio maksimalaus įtempimy intensyvumo priklausomybé nuo jo pagrindo tampriosios dalies kūgiskumo

Fig 6. The maximum stress intensity dependence upon cantilever spring seal elastic zone cone

Idomu pažymèti, kad esant dideliam darbo terpès slègiui, nagrinèjamu atveju $40 \mathrm{MPa}$, maksimalus įtempimų intensyvumas padidejja tik apie $6 \%$, o kontaktinè jèga - iki 50\%. Tai rodo, kad slègis veikia kitas zonas nei kontakte koncentruota apkrova.

Sandariklio santykinis skersmuo $\mathrm{D}_{\mathrm{s}}$, kaip ir buvo tikètasi, turi įtakos įtempimy̨ intensyvumui $\sigma_{\mathrm{I}}$, kontaktinio slègio jègai $F$ ir kontaktiniam slègiui $\mathrm{q}_{1}$ tik tada, kai jis mažas (mažesnis nei $80 \mathrm{~mm}$ ). Kaip matyti 7 paveiksle, kai sandariklio skersmuo didesnis nei $150 \mathrm{~mm}$ (santykinis skersmuo matuojamas viduriniame sandarinimo zonos taške), jo įtakos galima nepaisyti. Nagrinèjamu atveju maksimalūs tamprūs poslinkiai pasiekiami, kai lingè (medžiagos takumo riba $1200 \mathrm{MPa}$ ) iveržiama iki $0,12 \mathrm{~mm}$. Jeigu leistume nedideles plastines deformacijas, tai tampri jų dalis taip pat padidètų, tačiau didinti įveržimą daugiau nei $0,15 \mathrm{~mm}$ vargu ar tikslinga, nes tada plastiškai deformuosis visa lingè. 


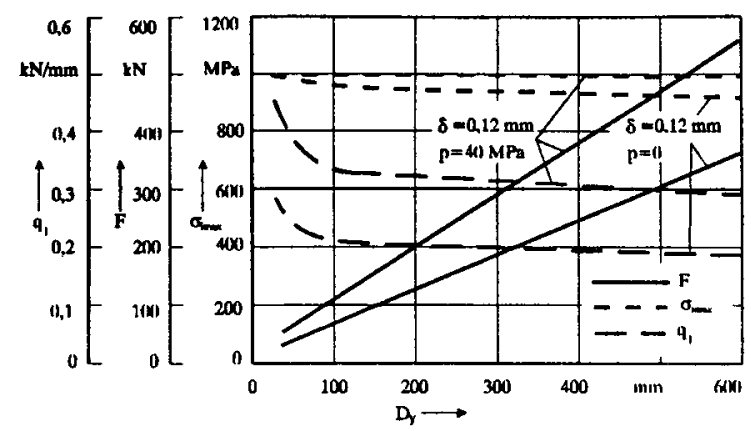

7 pav. Linginio sandariklio maksimalių ịtempimy intensyvumo $\sigma_{\mathrm{I}}$, kontaktinio slégio jëgos $\mathrm{F}$ ir kontaktinio slègio $q_{1}$ reikšmių priklausomybè nuo jo santykinio skersmens

Fig 7. Numerical solution profiles for cantilever spring seal problem: ratio of relative seal radius against maximal stress intensity $\sigma_{\mathrm{l}}$, pressure force $F$ and contact pressure $q_{1}$

\section{Sandarikliy dangy deformavimas}

Toliau apžvelkime dangos deformavimo procesą. Pastebèta, kad esant nedidelèms apkrovoms įtempimų ir deformaciju laukai, tiek ịvertinant trintị, tiek jos nepaisant yra būdingi klasikinei pusplokštumès ir cilindro sąveikai [1]. Toliau deformuojant vaizdas smarkiai keičiasi. Labai padidèja kontakto plotis, o dangoje esanti centrinè itempimy ittensyvumo ir deformaciju zona (plastinis branduolys) išsiplečia $\mathfrak{i}$ kontakto kraštus ir net išeina $\mathfrak{i}$ kontaktini paviršiu (kai apkrovos mažesnès, ši zona glūdi šiek tiek giliau ir nuo kontaktinio paviršiaus ją skiria plona tampri zona). Esant didelèms kontaktinèms jëgoms aiškiai išsiskiria trys maksimaliu ittempimy ir deformacijų zonos, išsidèsciusios kontakto centre ir kraštuose.

Jei danga plona (50 $\mu \mathrm{m}$ ir plonesnè), dideliu itempimu ir deformacijy zona susiformuoja ties skiriamuoju dangos ir keteros paviršiumi (8 pav.) ir esant nedidelèms kontaktinèms jẻgoms, todèl danga gali būti atplèšta nuo keteros.

Norint detaliau ištirti trinties įtaką (kontakto poroje) sandariklio dangos deformuotojo büvio parametrams, buvo atlikti kity tipu sandarikliy skaičiavimai, kuriuose dangu plastinès deformacijos siekia iki $100 \%$. Paaiskejo, kad trintis kontakto poroje turi itakos tiek deformuotos dangos formai, tiek kitiems jos būvio parametrams. Ši įtaka tuo didesne, kuo didesnés apkrovos ir kuo didesnis sausosios trinties koeficientas $\mu$.

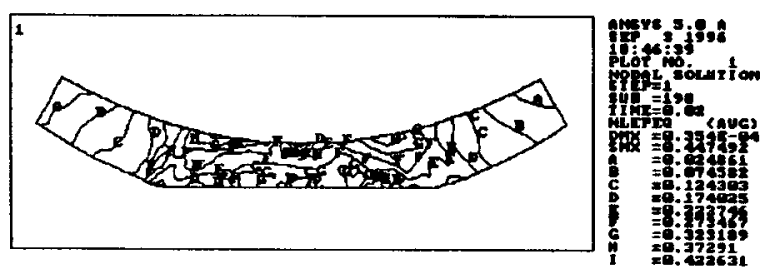

8 pav. $0,1 \mathrm{~mm}$ storio dangos plastiniy deformacijy
izolinijos

Fig 8. Contours of equivalent plastic strains of coating which thickness is $0,1 \mathrm{~mm}$

Apibendrinus visus skaičiavimu rezultatus, gautos priklausomybès tarp paviršių suartèjimo, kontaktinès jègos bei sandarinimo kokybę nusakančio parametro santykio $q / \sigma_{y}(q-$ vidutinis kontaktinis slègis, $\sigma_{\mathrm{y}}$ - medžiagos takumo riba) ir kontakto pločio. Pažymètina, kad santykis $q / \sigma_{y}$, kai dengiamo paviršiaus suapvalinimo spindulys $0,5 \mathrm{~mm}$, praktiškai yra pastovus dydis ir lygus $\approx 16$. ( 9 pav.) Didèjant keteros suapvalinimo spinduliui santykis $q / \sigma_{y}$ jau nelieka pastovus ir didèja didejjant kontaktinei jègai.

Taigi projektuojant sandariklius su dangomis reikia atsižvelgti $\mathfrak{i}$ tai, kad plastinès deformacijos artimiausiuose indentoriui sluoksniuose didèja, didinant kontaktinį slègi $F_{k}$, mažinant indentoriaus spindulį ir dangos storị.

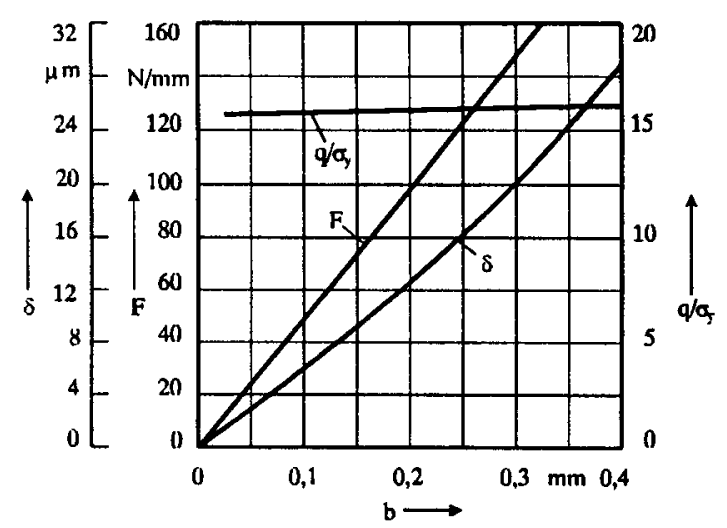

9 pav. Sandarinamų pavirsių suartẻjimo $\delta$, santykinès kontaktinés jègos $F_{\mathbf{k}}$ ir santykio $q / \sigma_{\mathbf{y}}$ priklausomybès nuo kontakto plocio, kai vario danga yra $0,14 \mathrm{~mm}$ storio, o indentoriaus suapvalinimo spindulys lygus $0,5 \mathrm{~mm}$

Fig 9. Numerical solution profiles for seals coating problem: ratio contact with against approach off contact surfaces $\delta$, relative contact force $F_{k}$ and relation $q / \sigma_{y}$, when coating thickness is $0,14 \mathrm{~mm}$ and radius of indenter $0,5 \mathrm{~mm}$ 


\section{Išvados}

Atlikti skirtingų tipų sandariklių skaiciavimai leidžia daryti tokias išvadas:

- kūginiams sandarikliams yra būdingas geometrinis ir plastinis nestabilumas esant palyginti nedidelèms apkrovoms. Be to, plastinis nestabilumas sukelia konstrukcijos antrosios formos geometrini nestabilumą. Dèl sandariklio nusèdimo $̧ \grave{i}$ forma geometriłkai nèra taisyklinga. Todèl labai apspausti kūginị sandariklį netikslinga, nes tampri konstrukcija gali tapti nesimetriß̌ka ašiai. Pagal standarto GOST 19755-84 reglamentuojamus matmenis kūginio sandariklio stabilumas paprastai prarandamas, kai apspaudimas didesnis kaip 1,2 mm. Naudojant tokius sandariklius:

- būtina tinkamai parinkti sandariklio medžiagas. Geriau tinka medžiagos, kurių aukštesnẻ takumo riba ir didesnis stiprèjimo koeficientas;

- reikia siekti, kad sandariklis ir sugniuždytas išlaikytų ašiai simetrišką formą. Tam galima padidinti sandarinimo irenginiui keliamus tikslumo reikalavimus (H8/e9 ir H8/f9 galima pakeisti bent atitinkamai i $\mathrm{H} 8 / \mathrm{f7}$ ir $\mathrm{H8} / \mathrm{e} 7)$.

- tikslinga šio tipo sandariklius padengti minkštomis dangomis, kas leistų sumažinti reikiamą hermetiskumui pasiekti ìveržimo jègą. Tokiu atveju plastiškai deformuotųsi tik danga, o pati konstrukcija išliktų tampri.

- Projektuojant sandariklius su dangomis, reikia ivertinti tai, kad plastinès deformacijos artimiausiuose indentoriui sluoksniuose dideja didinant kontaktinį slègi $F_{k}$, mažinant indentoriaus spinduli ir dangos storị.

\section{Literatūra}

1. К.Джонсон. Механика контахтного взаимодействия / ПІер. с англ. М.: Мир, 1989. 510 с.

2. J.Lubliner. Plastisity theory. New York, 1990. 495 p.

3. В.М.Александров, С.М.Мхитарян. Контактные задачи для тел с тонкими похрытиями и прослойками. М.: Наука, 1983. $488 \mathrm{c}$.

4. ANSYS Engineering Analysis System - Rev. 5.0A, Vol.IV. Theory. Swanson Analysis Systems, Inc. Houston, PA 15342-0065, 1992.

5. Уплотнение и уплотнитељьная техника: Справочник / Л.А.Кондаков, А.И.Голубев, В.Б.Овандер и др. Под общ. ред. А.И.Голубева, Л.А.Кондакова. М.: Маши ностроение, $1986.464 \mathrm{c}$.
Iteikta 19970304

\section{ANALYSIS OF CONTACT PROBLEMS IN ELASTIC . PLASTIC METAL SEALS}

\section{Eidukynas, R. Barauskas}

$S$ u m m a $r$ y

One of the most important problems in the design of seal joints is the optimisation of their shape and the material properties. This paper presents the results of the numerical simulation of conical and cantilever seal joints contact problems by using the finite element system ANSYS 5.0A. The temperature and friction have been taken into account.

The sealing principle of conical seals, which are usually used as flange joints in networks of pipes, is based on large plastic deformations of seal edges and maintaining the highly elastic property of the whole construction of the seal. Fig 1 presents the scheme of the conical seal used as a base for numerical simulations.

The relation between the contact force and displacement in conical seals with various material hardening shows that the contact force is not proportional to the displacement. The latter statement is demonstrated by Fig 2, presenting the results of the numerical simulations, where the curves $1,2,3$ correspond to the following numerical values of material properties curve 1 . $E=2,1 \cdot 10^{5} \mathrm{MPa}, \sigma_{\mathrm{y}}=280 \mathrm{MPa}, \mathrm{E}_{\mathrm{k} 1}=7000 \mathrm{MPa}$ $(\varepsilon \leq 0,0125), \mathrm{E}_{k 2}=2500 \mathrm{MPa}(0,0125<\varepsilon \leq 0,0125)$, $\mathrm{E}_{k 3}=600 \mathrm{MPa}(0,1<\varepsilon \leq 0,3), \mathrm{E}_{k 4}=1000 \mathrm{MPa}(\varepsilon>0,3)$, curve $2-\mathrm{E}=2,1 \cdot 10^{5} \mathrm{MPa}, \sigma_{\mathrm{y}}=200 \mathrm{MPa}, \mathrm{E}_{\mathrm{k}}=5 \cdot 10^{3} \mathrm{MPa}$; curve $3-E=2,1 \cdot 10^{5} \mathrm{MPa}, \sigma_{\mathrm{y}}=500 \mathrm{MPa}, \mathrm{E}_{\mathrm{k}}=3 \cdot 10^{3} \mathrm{MPa}$.

Under displacement $0,7-1,3 \mathrm{~mm}$, the cone seal usually loses stability by exhibiting the second form of instability. Such a sealing joint is not suitable for the practical application as it is not hermetic. Fig 3 shows the deformed shape and contours of the equivalent plastic strains of the above-mentioned conical seal (RAD1 $=0,153 \mathrm{~m}, \mathrm{RAD} 2=0,159 \mathrm{~m}, \mathrm{~h}=0,001 \mathrm{~m}, \mathrm{~A}=0,0007 \mathrm{~m}$, $\alpha=60^{\circ}, \beta=0^{\circ}, \varphi=10^{\circ}, \gamma=45^{\circ}, E=2,1.10^{\circ} \mathrm{MPa}$, $\sigma_{\mathrm{y}}=280 \mathrm{MPa}, \mathrm{E}_{\mathrm{k} 1}=7000 \mathrm{MPa}(\varepsilon \leq 0,0125), \mathrm{E}_{\mathrm{k} 2}=2500 \mathrm{MPa}$ $(0,0125<\varepsilon \leq 0,0125), \mathrm{E}_{k 3}=1600 \mathrm{MPa}(0,1<\varepsilon \leq 0,3)$, $\left.\mathrm{E}_{\mathrm{k} 4}=1000 \mathrm{MPa}(\varepsilon>0,3), v=0,3\right)$ in one of the loading steps of the solution process.

Numerous numerical simulations have shown that the second form of instability is caused by unfavourable loading and boundary conditions for the first instability form. Such numeric results correspond exactly to the experiments.

Under high pressure of the working medium (over $40 \mathrm{MPa}$ ), such seals collapse by exhibiting the first form of instability. The contact force increases only by $10 \%$, and the collapse occurs when the seal is loaded more than $1,4 \mathrm{~mm}$.

$\mathrm{V}$ - and $\lambda$ - form (cantilever) seals may recover from static and $0,1-0,4 \mathrm{~mm}$ dynamic displacements due to their high elasticity. Usually such seals possess soft metallic or polymeric coats. The process of the seal deformation is very complex because the contact surface slides and rolls upon the basic surface. 
In this paper the problem has been solved be using the submodelling techniques of ANSYS. The submodelling involves analysing a coarse model and by subsequently creating the finely meshed "submodel" of the region of interest. The coarse model displacements are applied as constraints on the cut boundary of submodel. In this problem, we will use the region of the whole cantilever seal as the coarse model. The region of interest is the contact zone, so we create the submodel of this region. Due to symmetry, only half a seal needs to be modelled (Fig 4), where $\mathrm{RADX}=3 \mathrm{~mm}, \mathrm{~S} 1=5 \mathrm{~mm}, \mathrm{H} 1=1,7 \mathrm{~mm}$, $\mathrm{H} 2=0,5 \mathrm{~mm}, \mathrm{~S} 2=0,5 \mathrm{~mm}, 3=2,8 \mathrm{~mm}, \mathrm{~S} 3=5,5 \mathrm{~mm}$, RAD1 = RAD2 = RAD3 = $1 \mathrm{~mm}, R A D Y=4 \mathrm{~mm}$, $\mathrm{RADC}=30 \mathrm{~mm}, \mathrm{DD}=0,1 \mathrm{~mm}, \delta=0,12 \mathrm{~mm}, \mathrm{E}=2,1 \cdot 10^{5} \mathrm{MPa}$, $v=0,3$.

After numerous numerical simulations, the base relations were defined. The maximum stress intensity dependence against the parameters of the arms of the cantilever spring seal elastic zone (Fig 6); ratio of relative seal radius against maximal stress intensity $\sigma_{\mathrm{I}}$, pressure force $F$ and contact pressure $q_{1}$ (Fig 7). The analysis enabled to obtain the optimised construction of the seal.

The elastic-plastic deformation analysis of the coating has been performed. When the loads are small, the stress and strain contours are characteristic of classic Hertzian [1] contact theory. With higher loads, the picture changes significantly. After increasing the contact area width, the plastic zone grows and develops through to the boundaries of the interacting region.

By summarising the simulation results were obtained: the relations between the contact width, the approach of the contact surfaces $\delta$, relative contact force $F_{k}$ and ratio $q / \sigma_{y}$, when coating thickness is $0,14 \mathrm{~mm}$ and radius of the indenter $0,5 \mathrm{~mm}$. The relation $q / \sigma_{y}$ in this case is constant, approximately equal to 16 . With the increase of the indenter radius, the ratio $q / \sigma_{y}$ is not constant and increases with an increase of the contact force.

The numerical simulations of various seals allow to arrive to the following conclusions:
1. For cone seals the geometric instability (usually in the second form) is exhibited even at computatively small loads. When the loading exceeds $1,2 \mathrm{~mm}$, the elastic structure may acquire an unaxisymmetric form. In the usage of such seals, the following points should be taken into account:

- it is necessary to match the materials properly. Best suitable materials have higher yield point and higher stiffness hardening;

- try to keep axisymmetric form of a seal even under the collapse. For this reason it is necessary to keep high requirements;

- good results are obtained by covering the seals with soft coatings, thus reducing the force. In such way only the coating is subjected to the plastic deformation, while the whole structure remains elastic.

2. Cantilever seals have good elastic properties and do not loose stability. After summarising the numerical simulations results, the suggestions for the rational geometric shape of the cantilever seal have been made.

3. In the design of coated seals it is necessary to take into account that the equivalent plastic strains in the coat layers close to the indenter increase with increasing contact force, decreasing the indenter radius and the coat thickness.

Rimantas BARAUSKaS. Doctor Habil, Professor. Department of Engineering Mechanies. Kaunas University of Technology. 37 Mickeviciaus, 3000 Kaunas.

Doctor's degree in mechanics in 1981. Doctor's Habil degree in 1992. Research interests: non-linear dynamic analysis, finite element programming

Valdas EDUKYNAS. Doctor. Department of Engineering Mechanics. Kaunas University of Technology. 37 Mickeviciaus, 3000 Kaunas.

Doctor's degree in mechanics in 1996. Research interests: non-linear structural analysis, finite element programming. 